\title{
O BARIERACH KULTUROWYCH W TŁUMACZENIU TEKSTÓW SPECJALISTYCZNYCH NA PRZYKEADZIE TEUMACZENIA DÉCLARATION DE PORTE-FORT
}

,N $\mathrm{N}^{\mathrm{i}}$ erozerwalność związku kultura-komunikacja wynika [...] z funkcjopod ktorym tresci socjokulturowe moga spełniac role mediatora hasłem, pod którym treści socjokulturowe mogą spełniać rolę mediatora w procesach tworzenia i interpretowania aktów komunikacji” (Duszak, 1998: 243). Istotnie, każdy tekst jest uwarunkowany społecznie, a więc i kulturowo usankcjonowanym systemem zachowań werbalnych zarówno nadawczych, jak i odbiorczych. Szczególnie wysoki stopień skonwencjonalizowania kulturowego widoczny jest w tekstach specjalistycznych, sprzęgających cechy podyktowane specyfiką danej dziedziny na poziomie językowym i tekstologicznym, z cechami wynikającymi z „zasad regulujących adekwatne posługiwanie się wiedzą językową i kulturową" (ibidem: 253). Odczuwa to szczególnie tłu- 
macz skonfrontowany nie tylko z odmiennościami rzeczywistości pozajęzykowej oraz z różnicami w sposobie jej ujmowania na poziomie języka, ale także z odrębnościami komunikacyjnymi zarejestrowanymi w samej strukturze tekstu.

Niniejszy artykuł zawiera refleksje będące owocem paroletniej praktyki w dydaktyce przekładu tekstów specjalistycznych, które przedstawię, skupiając się na trzech składających się na nie zagadnieniach: charakterystyki tekstów specjalistycznych, barier kulturowych oraz związanych z nimi problemów przekładowych.

\section{Wokół tekstów specjalistycznych}

Mówiąc o tekstach specjalistycznych (TS), nasuwa się pytanie o ich definicję. A ponieważ nie ma wśród tekstologów jednomyślności już na poziomie konceptualizacji, opieram się na ogólnej definicji S. Gruczy, w świetle której „teksty specjalistyczne to teksty wytworzone przez specjalistów w celu wyrażenia odpowiedniej specjalistycznej wiedzy" (2004: 150), charakteryzujące się pewną autonomią kontekstową, tzn. że ich rozumienie nie jest uzależnione od zewnętrznych kontekstów, w jakich się dokonuje (ibidem: 150).

Teksty specjalistyczne są, $\mathrm{w}$ różnym oczywiście stopniu, skonwencjonalizowane w strukturze pionowej, zwanej makrostrukturą, stanowiącej matrycę, która definiuje kolejność aktów mowy oraz ich prezentację typograficzną, jak również w strukturze poziomej czyli mikrostrukturze, określającej reguły na poziomie realizacji językowej poszczególnych tych aktów.

Każdy tekst specjalistyczny realizuje się w trzech płaszczyznach: semantycznej, syntaktycznej i pragmatycznej, przy czym dwie pierwsze podporządkowane są ostatniej (Troszczyńska-Nakonieczna 2003: 256). Podporządkowanie to odbywa się zasadniczo na trzech poziomach: treściowym, językowym i typograficznym. Dodatkowo każdy z wymienionych poziomów rozszczepia się na dwa obszary elementów specyficznych i elementów niespecyficznych (ibidem).

Na poziomie treściowym, obok informacji zdeterminowanych socjokulturowo znajdują się więc elementy niezdeterminowane socjokulturowo; na poziomie językowym, z konwencjami specyficznymi, stanowiącymi o przynależności danego tekstu do określonego gatunku, sąsiadują elementy niespecyficzne. Na poziomie typograficznym natomiast rozróżnić można jednocześnie środki graficzne interkulturowo wspólne jak również te zdeterminowane socjokulturowo (ibidem: 257). 
O BARIERACH KULTUROWYCH W TŁUMACZENIU TEKSTÓW SPECJALISTYCZNYCH...

Wszystkie wymienione zależności ilustruje następujący schemat ${ }^{1}$ :

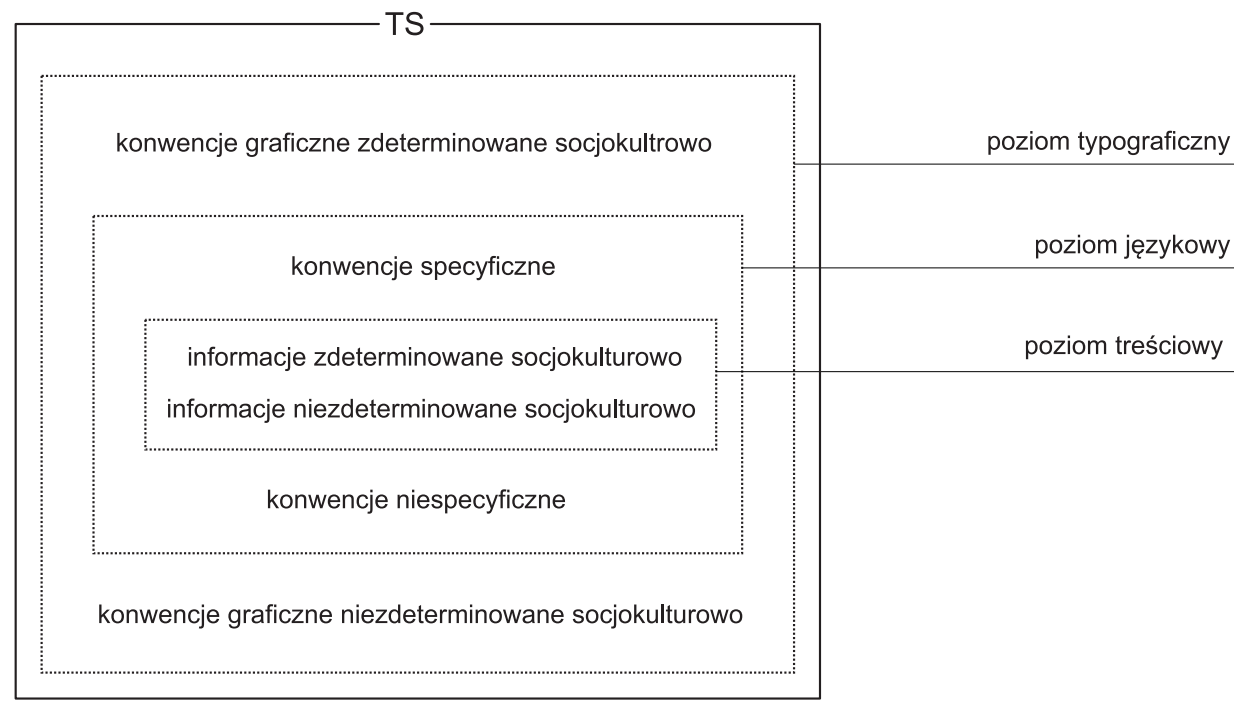

W celu poprawnego przetłumaczenia danego tekstu specjalistycznego, tłumacz zobowiązany jest dokonać właściwej identyfikacji elementów specyficznych i niespecyficznych, bo tylko w ten sposób może określić z jednej strony to, co jest inwariantem i dobrać adekwatne techniki tłumaczenia, $z$ drugiej zaś ustalić podobieństwa i rozbieżności w ujmowaniu rzeczywistości pozajęzykowej odpowiadającej danej dziedzinie specjalizacji.

Identyfikacja wymienionych elementów powinna przebiegać według poniższej trajektorii:

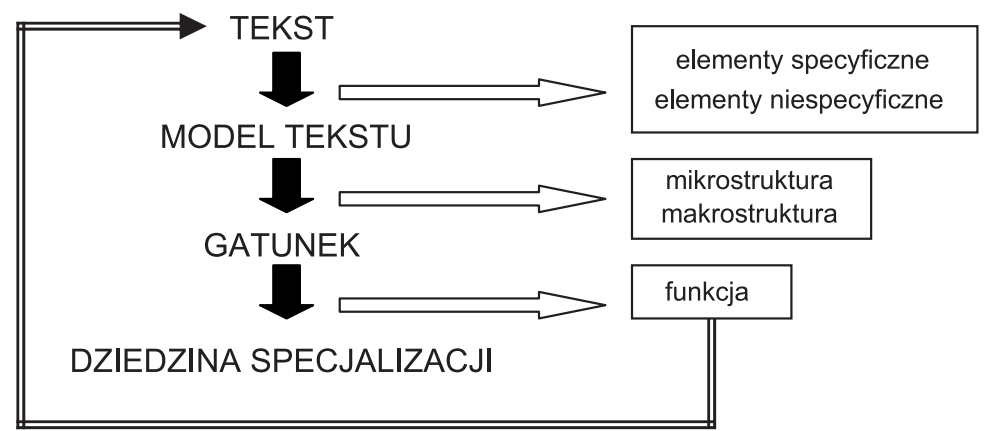

1 Rysunek został opracowany na podstawie schematu autorstwa S. Göpferich przedstawionego [w:] Troszczyńska-Nakonieczna 2003: 256. 
Analiza danego tekstu w kontekście modelu tekstu ujawnia elementy specyficzne i niespecyficzne, które, na tle gatunku, wyznaczają mikrostrukturę i makrostrukturę o pragmatycznie zdefiniowanej funkcji.

Przedstawiony algorytm pozwoli nie tylko właściwie zinterpretować konkretny tekst specjalistyczny mający swój odpowiednik w języku docelowym, ale okaże się szczególnie cenny w przypadku tłumaczenia tekstów bezekwiwalentowych. Istotnie, na podstawie mikrostruktur zdefiniowanych na poziomie gatunku, można zrekonstruować tekst wyjściowy elementami właściwymi konwencji tekstologicznej języka docelowego, uwzględniając makrostrukturę tekstu wyjściowego. To pozornie zawiłe wyjaśnienie można zilustrować w sposób następujący:

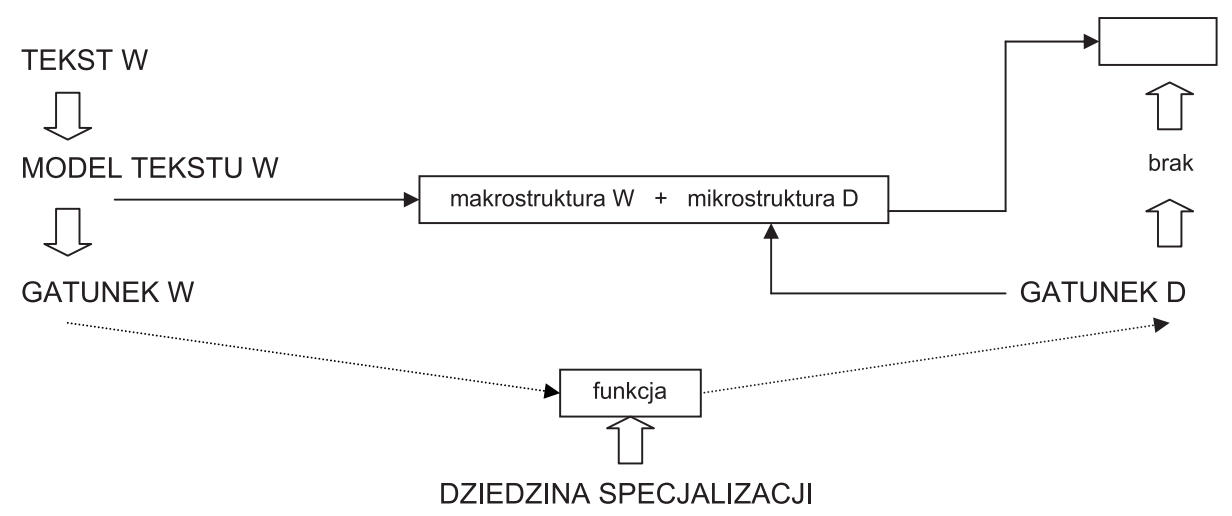

Sytuacja tłumacza stojącego w obliczu obowiązku przetłumaczenia takiego tekstu w praktyce okazuje się jednak daleko bardziej skomplikowana, a to za sprawą licznych barier wynikających w głównej mierze z nieuświadomienia sobie naturalnych różnic istniejących między kulturą wyjściową a kulturą docelową.

\section{Wokół różnic kulturowych}

Wyjaśnienie barier kulturowych w przekładzie tekstów specjalistycznych wymaga odwołania się do definicji samego pojęcia kultury. Według J. Boltena, „pojęcie kultury [...] obejmuje w równym stopniu wzajemne oddziaływania z przyrodniczym otoczeniem [...], co obszar kultury jako instancji nadającej sens oraz obszar «kulturotwórczy» w wąskim znaczeniu" (Bolten 2006: 27). Tak zdefiniowana kultura „obejmuje wszelkie wyrazy życia tych, którzy ten świat współtworzyli i współtworzą. Należą tu w równym stopniu religia, ety- 
ka, prawo, technika, system kształcenia, materialne i niematerialne produkty, co [...] problemy środowiskowe" (ibidem).

W świetle przytoczonej definicji kulturowy charakter mają wszelkie różnice składające się na odrębność każdego państwa i jego szeroko pojętej kultury w wymiarze synchronicznym i diachronicznym. Te z nich, które w istotny sposób partycypują w procesie przekładu tekstów specjalistycznych, niejednokrotnie będąc bezpośrednim źródłem błędów w tłumaczeniach, można podzielić na trzy grupy:

a) różnice na poziomie rzeczywistości pozajęzykowej obejmujące zarówno rzeczywistość materialną, jak i niematerialne parametry i aspekty jej funkcjonowania. W grupie tej znajdują się ponadto wszystkie części kontekstu socjokulturowego pełniącego rolę regulatora $\mathrm{w}$ procesach nadawania i odbierania mniej lub bardziej zinstytucjonalizowanych form komunikacji werbalnej, które decydują o ostatecznym powiązaniu elementów kontekstu pragmatycznego z daną wypowiedzią językową;

b) różnice na poziomie tekstologicznym, wynikające z rozbieżności modeli tekstów pełniących analogiczną funkcję. Charakterystyka danego gatunku tekstu odzwierciedla sytuacyjne i funkcjonalne użycie terminów i wyrażeń, będąc jednocześnie wyznacznikiem konwencji tekstowych, zwrotów i sformułowań typowych w określonej sytuacji komunikacyjnej. Modele tekstów „należą do struktur antycypacji w dyskursie i funkcjonują jako schematy wiedzy użytkowników języka" (Duszak 1998: 176), przez co każdorazowe „uruchomienie schematu wywołuje [...] oczekiwanie określonego kierunku jego dalszego rozwinięcia" (ibidem). Z tego wynika, że dany model tekstu opiera się na społecznie akceptowanych strategiach komunikacyjnych właściwych danemu kontekstowi i na społecznie przyjętych formach utekstowiania znaczeń. W dalszej części omówię pokrótce szczególny przypadek różnic tej natury, w którym konkretny tekst prawniczy odpowiadający określonemu aktowi prawnemu w kulturze wyjściowej nie ma ekwiwalentu tekstowego w kulturze docelowej;

c) różnice na poziomie językowym, zasadzające się m.in. na nieprzystawalności zakresu semantycznego pojęć będących odpowiednikami tylko w określonych kontekstach. Właściwy dobór terminów stanowi istotną fazę tłumaczenia i wymaga od tłumacza, oprócz kompetencji translatorskiej, wiedzy fachowej i kulturowej. Ta ostatnia jest niezbędna nie tylko w odniesieniu do tekstów pochodzących $z$ diametralnie różnych systemów prawnych, lecz także $\mathrm{w}$ odniesieniu do tekstów pochodzących $\mathrm{z}$ systemów prawnych o niemałym podobieństwie, jak w przypadku polskiego i francuskiego. Wspólny rdzeń, wynikający $\mathrm{z}$ jednej strony $\mathrm{z}$ samej natury prawa, $\mathrm{z}$ drugiej zaś $\mathrm{z}$ uwa- 
runkowań historycznych, jest tyleż ułatwieniem, co utrudnieniem, gdyż odpowiedniki terminologiczne istniejące w językach wyjściowym i docelowym, nierzadko są ekwiwalentnymi znaczeniowo tylko pozornie.

Wymienione poziomy różnic kulturowych sprzężone są hierarchią intralingwalnych zależności intertekstualnych, powodujących, że „spójność (tekstu) wchodzi w obszar intencji i oczekiwań komunikacyjnych, przekraczając w ten sposób linię podziału semantyka-pragmatyka" (Duszak 1998: 101). Istotnie, poszczególne terminy odsyłają do konkretnych pojęć zdefiniowanych w różnych tekstach prawnych, podobnie jak każdy tekst prawny czy prawniczy jest konstruktem prefabrykowanym w dwóch modułach - mikrostrukturalnym i makrostrukturalnym. Oznacza to, że zarówno dobór terminów i sformułowań oraz sposób komponowania treści językowej, jak również określenie kryteriów pragmatycznych jego użycia podlega ścisłej, usankcjonowanej społecznie kodyfikacji. Co więcej, poszczególne modele tekstów z funkcjonalnie im przypisanym asortymentem terminów są zakotwiczone w świadomości ich użytkowników na poziomie konotacji, co nakłada na tłumacza szczególną dbałość o to, by przekład tekstu korespondował nie tylko z normą językową, ale również z poczuciem językowym jego użytkowników. Intertekstualność pełni istotną funkcję w tłumaczeniu tekstów specjalistycznych, gdzie na jej wymiar intralingwalny nakłada się wymiar interlingwalny, gdyż tłumaczony tekst jest w relacji intertekstualnej w odniesieniu do konwencji tekstowych zarówno języka wyjściowego, jak i języka docelowego (por. Kielar 2003: 47).

$\mathrm{Na}$ tę skomplikowaną kombinację barier kulturowych nakłada się pokutujący w dalszym ciągu stereotyp tłumaczenia tekstów specjalistycznych, ograniczający arsenał możliwości translatorskich do strategii tłumaczenia dosłownego, błędnie uznawanej za jedynie słuszną. Prowadzi to często do utrwalenia, zwłaszcza u początkujących w dziedzinie tekstów specjalistycznych tłumaczy, groźnej postawy uciekania się do słownika jako do pierwszej i ostatniej instancji rozstrzygającej o poprawności wybranych rozwiązań terminologicznych, z pominięciem fazy dewerbalizacji. Błędne koło przekonania, że im bardziej specjalistyczny tekst, tym bardziej należy trzymać się litery tekstu, potęguje świadomość braku zawodowych kompetencji w dziedzinie, z której pochodzi tekst. Tłumacze wywodzą się bowiem najczęściej z grupy absolwentów studiów w zakresie języków obcych, z mniej lub bardziej wykształconym nawykiem poszerzania wiedzy fachowej $\mathrm{w}$ danej dziedzinie. Często jednak wiedza ta jest na tyle powierzchowna, że tłumaczący „nie jest w stanie tłumaczyć «przez treść», ale zazwyczaj naśladuje w przekładzie cechy powierzchniowe tekstu j1" (Kielar 2003: 152). Tym samym utrudnia rekonstrukcję sensu tekstu wyjściowego (j1) na trzech poziomach jego spójności: 
- na poziomie semantyczno-tematycznym, odpowiedzialnym za spójność międzywyrazową i międzyzdaniową,

- na poziomie dyskursywnym, na którym dokonuje się hierarchizacja informacji względem siebie w funkcji struktury danego modelu tekstu,

- na poziomie pragmatycznym, gdzie dochodzi do konfrontacji i integracji konstrukcji semantycznej z docelowym odniesieniem pozajęzykowym.

Zachwianie spójności globalnej na którymkolwiek z poziomów prowadzi do niezgodności sensu tekstu docelowego z sensem tekstu wyjściowego, powodując nieprzystawalność treści semantycznej do właściwego mu fragmentu rzeczywistości pozajęzykowej.

Staje się to szczególnie jaskrawe wtedy, gdy akt komunikacyjny odpowiadający tekstowi wyjściowemu nie ma dokładnego odpowiednika tekstowego w języku docelowym.

\section{Wokół problemów z przekładem}

Tego typu sytuacja zaistniała w przypadku dokumentu francuskiego Déclaration de porte-fort, zadanego do przetłumaczenia zarówno studentom uczącym się przekładu tekstów specjalistycznych (studenci IV roku filologii romańskiej w ramach zajęć specjalistycznych), jak i osobom ze sporym niejednokrotnie doświadczeniem zawodowym w dziedzinie tłumaczenia (w tym słuchacze Podyplomowego Studium Kształcenia Tłumaczy Języka Fracuskiego). Wśród około 40 prac nie znalazło się ani jedno poprawne tłumaczenie, a liczne nieprawidłowości translacyjne dowodzą powszechności złego nawyku, który najwyraźniej zaprezentował się w wersji zaproponowanej przez tłumacza z długoletnią już praktyką.

Omawiany dokument ma postać prefabrykowanego formularza, wypeknianego przez jednego ze spadkobierców uprawnionych do pobierania emerytury po zmarłym członku rodziny, pracującym niegdyś na terenie Francji. Charakteryzuje się on następującą strukturą pionową:

- tytul,

- preambuła określająca charakter dokumentu oraz osoby podpisującej, a jest nią jeden ze współdziedziczących spadek,

- tekst zasadniczy trójdzielny treściowo i graficznie, zawierający: przedstawienie wnioskodawcy, oświadczenie wnioskodawcy, w którym ten wnosi o wypłacenie mu całości sumy należnej spadkobier- 
com po zmarłym członku rodziny uprawnionym do pobierania renty, by następnie rozdzielić ją pomiędzy współdziedziczących w stosunku do ich praw, oraz zobowiązanie, w którym wnioskodawca zgadza się ponieść odpowiedzialność za wszelkie ewentualne roszczenia z tytułu braku regularności w wypłacaniu współdziedziczącym należnych im kwot,

- elementy finalne, takie jak miejsce i data podpisania dokumentu, jak również podpis wnioskodawcy.

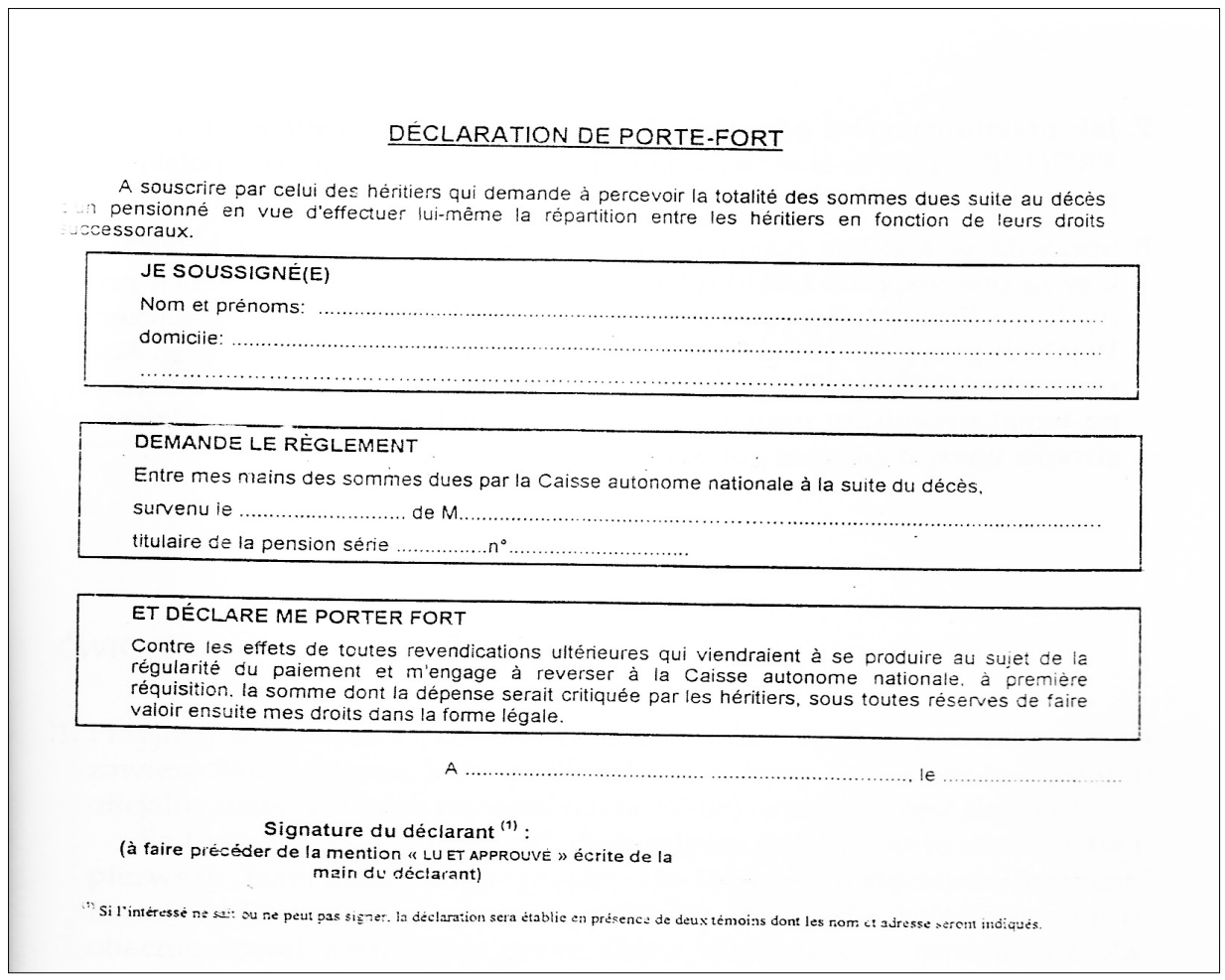

Na poziomie struktury pionowej, tekst docelowy stanowi wierne odwzorowanie tekstu wyjściowego. Zachowany jest układ wszystkich jego części, co jest zgodne z przyjętymi zaleceniami. Jednak wierne odwzorowanie poszczególnych sformułowań w obrębie struktury poziomej, czyli układu elementów składających się na daną część struktury pionowej, okazało się chybionym rozwiązaniem już na poziomie tytułu. Tytuł jest niezwykle istotnym elementem, pełniącym funkcję identyfikatora umożliwiającego właściwą interpretację tekstu. Jego brak czy nieodpowiednie przetłumaczenie może „utrudnić uruchomienie procesów interpretacyjnych i kontekstualizację znaczeń" (Jo- 
pek-Bosiacka 2006: 91). Jest to szczególnie groźne w przypadku braku ekwiwalentnego modelu tekstu w kulturze docelowej, gdyż nie dysponując prefabrykowaną matrycą interpretacyjną, odbiorca nie może dokonać korekty ewentualnego uchybienia tłumacza. A za takie niewątpliwie należy uznać przetłumaczenie tytułu Déclaration de porte-fort na Deklaracja gwarancji. Zarówno słowo deklaracja, jak i słowo gwarancja istnieją w polskim dyskursie prawniczym i zapewne to stwierdzenie utwierdziło tłumacza w przekonaniu o słuszności wyboru strategii tłumaczenia literalnego. Pozorna zbieżność leksykalna jest często źródłem tzw. fałszywych przyjaciół, nierzadkich w tłumaczeniach tekstów specjalistycznych, w czym ma swój udział wspomniany wcześniej stereotyp. Jednakże w omawianym przypadku połączenie obu tych terminów bez żadnej konkretyzacji na poziomie semantycznym skutkuje błędnym skojarzeniem ram interpretacyjnych z ekonomiczno-handlowym zakresem komunikacji.

Tłumaczenie tytułu jest zatem niepoprawne, bo nie tylko nie sygnalizuje charakteru tłumaczonego dokumentu, ale też wprowadza niemile widzianą w dyskursie prawnym wieloznaczność. W ten sposób, zamiast tworzyć punkt odniesienia ustawiającego komunikat we właściwej ramie sytuacyjnej, tytuł tekstu docelowego narusza system oczekiwań odbiorcy, pozbawionego możliwości konfrontacji tekstu wyjściowego $\mathrm{z}$ analogicznymi dokumentami funkcjonującymi w kulturze języka docelowego. Powstaje reakcja łańcuchowa: bariera na poziomie językowym stwarza barierę natury tekstologicznej i dyskursywnej, a tym samym prawdopodobieństwo niewłaściwej identyfikacji odniesienia pozajęzykowego.

W ten sposób brak precyzji semantycznej na poziomie tytułu, zaistniały w wyniku niepoprawnie przyjętej strategii translacyjnej, przyczynia się do braku ekwiwalencji semantycznej tekstu. Całości dopełnia powielenie błędu w kluczowej dla dokumentu części zasadniczej, gdzie tłumacz umieścił następującą treść:

[...] i udzielam gwarancji skutków wszelkich roszczeń, jakie pojawiłyby się z tytułu nieregularności w płatności

w miejscu, gdzie powinno znajdować się zapewnienie o odpowiedzialności, którą wnioskodawca zobowiązuje się ponieść $w$ razie zakwestionowania regularności czy wysokości wypłacanych współdziedziczącym sum. Z zaproponowanego przez tłumacza rozwiązania nie wynika jasno, co on gwarantuje: czy skutki roszczenia (a tym samym pojawienie się nieregularności w wypłacaniu przedmiotowych kwot), czy własną za nie odpowiedzialność. Zaproponowa- 
ne rozwiązanie jest klasyczną kalką powstałą w wyniku nierozróżnienia elementów specyficznych i niespecyficznych na poziomie mikrostruktury, co wobec nieznajomości istniejących w języku docelowym ekwiwalentów zastępczych - doprowadziło do przetłumaczenia tych pierwszych dosłownie. Błędów jest więcej, a ich dokładna analiza doprowadziłaby do tego samego wniosku.

Bariera językowa wiąże się z barierą tekstologiczną na zasadzie sprzężenia zwrotnego: brak dokładnego odpowiednika tekstowego w języku docelowym dezorientuje tłumacza, czym wzmaga jego kurczowe trzymanie się litery tekstu wyjściowego tam, gdzie dewerbalizacja, czyli identyfikacja odniesienia pozajęzykowego, okazuje się jedynym rozwiązaniem prowadzącym do odtworzenia sensu na gruncie kultury docelowej. Przyjęty tok postępowania odzwierciedlający tłumaczenie „z tekstu na tekst”, przedstawia się następująco:

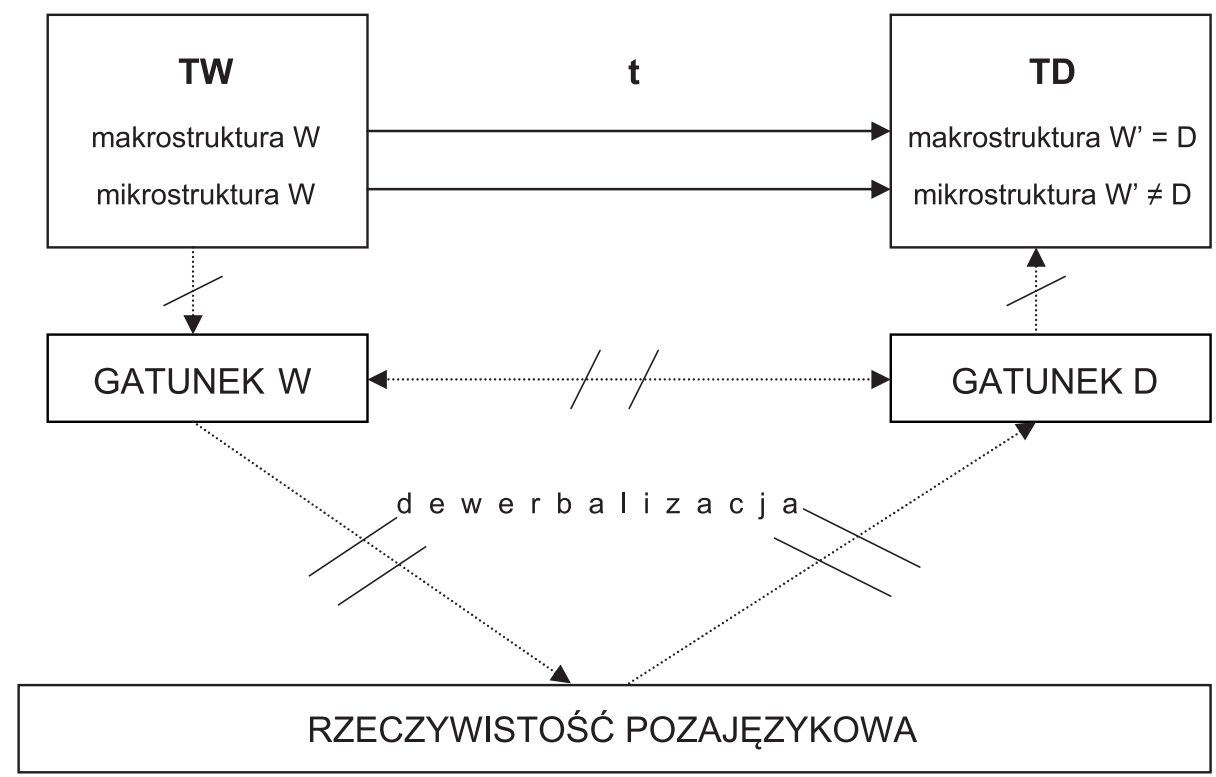

Pominięcie fazy dewerbalizacji pozbawiło tłumacza możliwości odniesienia się do polskiego systemu prawnego i zrekonstruowania dokumentu na podstawie terminów, frazeologii i sformułowań stosowanych w porównywalnej sytuacji. Bowiem o ile omawiany dokument nie ma ścisłego odpowiednika tekstowego, to podobne sytuacje dziedziczenia po zmarłym członku rodziny istnieją również w Polsce i - skrupulatnie opisane m.in. w polskim kodeksie cywilnym i w kodeksie postępowania cywilnego - regulowane są przy pomocy analogicznych funkcjonalnie dokumentów (wniosek o stwierdzenie na- 
bycia spadku, postanowienie o stwierdzeniu nabycia spadku, oświadczenie o przyjęciu spadku). W takich przypadkach intertekstualność na poziomie określonych gatunkowo mikrostruktur okazuje się niezawodną deską ratunku, gdyż wobec braku analogicznego dokumentu urzędowego, konwencje terminologiczne, frazeologiczne i stylistyczne są w zasięgu ręki tłumacza, który potrafi nie tylko zidentyfikować opisaną w dokumencie wyjściowym sytuację, ale też porównać ją $\mathrm{z}$ systemem prawnym w kulturze docelowej, jak również $\mathrm{z}$ obowiązującymi w niej dokumentami, by w miarę możliwości upodobnić poziom informatywności tłumaczenia w stosunku do oryginału. Dzięki temu tłumacz mógł przenieść treść tekstu wyjściowego z zachowaniem jego oryginalnego charakteru, nie powodując przy tym żadnej niejednoznaczności w odniesieniu do polskiego dyskursu prawniczego.

Rolę tekstów paralelnych w tłumaczeniu tekstów specjalistycznych można porównać do budowy domu według projektu stworzonego przez architekta działającego w kraju X, gdzie używa się danego materiału budowlanego, na terenie kraju Y, z wykorzystaniem innych materiałów, właściwych panującym tam zwyczajom budowlanym. Oczywiście nie obędzie się bez modyfikacji, bo każdy materiał budowlany cechuje się swoistą wytrzymałością, co pociąga za sobą konieczność zastosowania innych rozwiązań technicznych, niezbędne dla zachowania zamierzonego przez projektanta programu funkcjonalnego, który - jako swoista makrostruktura - pozostaje niezmienny i możliwy do odtworzenia praktycznie na każdej szerokości geograficznej.

Tłumacz jest w podobnej sytuacji: mając przetłumaczyć dany tekst wyjściowy, zanurzony w praktyce komunikacyjnej języka wyjściowego, musi sięgnąć do takich tekstów w języku docelowym, które tematycznie i funkcjonalnie powiązane są $\mathrm{w}$ mniejszym lub większym stopniu $\mathrm{z}$ tekstem wyjściowym. Dzięki temu, przy zachowaniu właściwej oryginałowi struktury pionowej, tłumacz może posiłkować się poszczególnymi elementami struktury poziomej wybranych tekstów w języku docelowym. Program funkcjonalny zostaje zatem odtworzony $\mathrm{z}$ użyciem budulca zaczerpanego $\mathrm{z}$ języka docelowego. Wymaga to oczywiście właściwej selekcji i ukontekstowienia znaczeń oraz odpowiedniego sformułowania ich zgodnie z konwencjami stylistycznymi przyjętymi w języku docelowym. W ten sposób, mimo braku dokładnego odpowiednika modelu tekstu w języku docelowym, tekst docelowy może spełniać normy społeczne w kulturze docelowej, określające sposoby administracyjnego komunikowania się $\mathrm{w}$ sytuacjach zbliżonych do sytuacji objętej tekstem wyjściowym. Przy właściwym bowiem podejściu, demonizowana (zbyt) często intertekstualność może się okazać doskonałym narzędziem w imporcie tekstologicznych nowości, stanowiąc nieocenioną furtkę pojęcio- 
wą do odmiennej kultury, która wspólne wszystkim sytuacje ujmuje w inne ramy komunikacyjne.

\section{Wnioski}

Prawdziwą barierą w tłumaczeniu tekstów specjalistycznych są zatem nie tyle różnice na wymienionych wcześniej poziomach, ile nieumiejętność ich odpowiedniego wykorzystania w przekładzie. $\mathrm{W}$ tym względzie cenne byłyby badania tekstologiczno-traduktologiczne ukierunkowane na analizę porównawczą gatunków i modeli tekstów charakterystycznych dla konkretnej dziedziny, ze szczególnym uwzględnieniem elementów specyficznych i niespecyficznych istniejących na każdym poziomie realizacji danej grupy tekstów. Studia takie, opatrzone wskazówkami na temat odpowiednich dla danych sytuacji strategii translatorskich, niewątpliwie uzmysłowiłyby kandydatom na tłumaczy i samym tłumaczom wielopoziomowe zależności na osi tekst specjalistyczny-rzeczywistość pozajęzykowa z dziedziny specjalizcji, umożliwiając tym samym wykształcenie nawyku poprawnej interpretacji, a co za tym idzie poprawnego tłumaczenia.

Świadomość wspomnianych zależności oraz zdeterminowanych nimi strategii przekładowczych przyczyniłaby się ponadto do wykorzenienia wcześniej omówionego stereotypu opartego na częstym wciąż przeświadczeniu, że kompetencja językowa jest jednoznaczna $\mathrm{z}$ kompetencją translatorską, a operacja przekładu rozgrywa się w językowym dwuwymiarze „z tekstu na tekst". Z drugiej zaś strony ukazałaby właściwy wymiar kompetencji tłumacza tekstów specjalistycznych, który nie będąc specjalistą w danej dziedzinie, nie musi znać wszystkich rozwiązań, ale powinien umieć je odnajdywać, korzystając $z$ wszelkich dostępnych mu środków, zwłaszcza tam, gdzie nie ma tekstowego odpowiednika oryginału. Bo też, ,jeżeli wszystko, co wyrażone, jest do zinterpretowania i jeżeli interpretacją można nazwać każdy przekład, to każdy zaistniały w kulturze tekst jest przetłumaczalny przez interpretacyjnie otwartego i językowo kompetentnego czytelnika" (Korniejenko 1995: 162).

\section{Literatura}

Bolten, J., 2006, Interkulturowa kompetencja, przeł. B. Andrzejewski, Poznań. Duszak, A., 1998, Tekst, dyskurs, komunikacja międzykulturowa, Warszawa. 
Grucza, S., 2004, Od lingwistyki tekstu do lingwistyki tekstu specjalistycznego, Warszawa.

Jopek-Bosiacka, A., 2006, Przekład prawny i sadowy, Warszawa.

Kielar, B.Z., 2003, Zarys translatoryki, Warszawa.

Korniejenko, A., 1995, „Dlaczego nieprzekładalność jest niemożliwa?”, [w:] Między oryginałem a przekładem I, Konieczna-Twardzikowa, J., Kropiwiec, U. (red.), Kraków, s. 155-163.

Troszczyńska-Nakonieczna, W., 2003, „Pragmatyczne aspekty badań gatunków tekstów specjalistycznych na potrzeby tłumaczeń i dydaktyki”, [w:] Języki specjalistyczne. Zagadnienia dydaktyki i przekładu, Mamet, P. (red.), Katowice, s. 247-259.

\section{On Cultural Barriers to Translating Specialist Texts: on the example of translation of déclaration de porte-fort}

\section{Summary}

The complexity of the relationship between language and culture is reflected in the multifaceted interplay between a text model and a corresponding context model. As an intermediary between two texts and thereby two contexts, the translator is involved in a double intracultural and intercultural relationship revealing an array of cultural differences that the author divides into three categories.

The author analysed a translation of a French legal text that has no textual equivalent in legal Polish; the translation was performed by people with varying translation experience. The author concludes that the real barrier to translating specialist text is not so much cultural differences as rather the inability to use them properly in translation. 